\title{
CORPORATE SOCIAL RESPONSIBILITY OF AGRICULTURAL ENTERPRISES ACCORDING TO THEIR ECONOMIC STATUS
}

\author{
Olga Popova ${ }^{1,}$ Viktor Koval $^{2}$, Liudmila Antonova ${ }^{3}$, Anna Orel ${ }^{4}$ \\ ${ }^{1}$ DSc., Institute for Economics and Forecasting of the National Academy of Sciences of Ukraine, \\ Panasa Myrnoho 26, 01011 Kyiv, Ukraine. E-mail: olgpomail@gmail.com \\ ${ }^{2}$ DSc., Assoc.Prof. Odessa Institute of Trade and Economics of Kyiv National University of Trade \\ and Economics, Inglezi 6, 65070 Odessa,Ukraine.E-mail: victor-koval@ukr.net \\ ${ }^{3}$ DSc., Petro Mohyla Black Sea National University, Ukraine. E-mail: antonovalv77@ gmail.com \\ ${ }^{4}$ Kharkiv National Technical University of Agriculture named after Petr Vasilenko, Ukraine. \\ E-mail:vova7003@gmail.com
}

Received 0205 2019; Accepted 30062019

The problem under consideration in this study is whether economically stronger enterprises, which have more opportunities, are really better at solving social and environmental challenges in the context of corporate responsibility than economically weaker ones. The aim of the article is to substantiate the interaction of agricultural enterprises and explore the levels of corporate social responsibility for individual components of five groups of agricultural enterprises grouped by performance indicators of their economic activities. Methods include statistical grouping with the allocation of five groups of enterprises are determined depending on the results of their economic activity, that is a volume of profitability and its level as indicators of economic efficiency, according to the information base of 9000 medium and large agricultural enterprises in Ukraine, using the method of statistical groupings. The results section represents compared data of the most enterprise groups over the seven-year period and the trends in their corporate responsibility have been estimated. According to the results of the study, agricultural enterprises with a higher level of economic activity didn't differ a lot from the smaller ones in the implementation of socially and environmentally responsible acts.

Key words: economics, social and ecological challenges, corporate social responsibility, earnings, profitability, economically stronger enterprises.

JEL Codes: D21, L21, M14, Q13.

\section{Introduction}

Corporate Social Responsibility (CSR), which for several decades has been voluntary for business, pretends to become obligatory, and thus the process of legislative consolidation of CSR can be catalyzed.

Copyright (C) 2019 The Authors. Published by Vytautas Magnus University, Lithuanian Institute of Agrarian Economics. This is an open-access article distributed under the terms of the Creative Commons Attribution-NonCommercial 4.0 (CC BY-NC 4.0) license, which permits unrestricted use, distribution, and reproduction in any medium, provided the original author and source are credited. The material cannot be used for commercial purposes. 
It's necessary to underline that corporate social responsibility means not only a longterm obligation of economic entity to behave in ethical way and to improve quality of the employees' vital activity, but it also concerns an ethical conduct with the environment of their business activity, that are communities, settlements, areas and society in general.

A multifunctional origin of agricultural enterprises requires balanced implementation of economic, social and ecological tasks, which allows to ensure constant agrarian and rural development. However, an economic determinism is prevalent, and social and ecological tasks are solved in the last turn. Nevertheless, it becomes more obvious that prevention of social and ecological problems is cheaper, than their solution.

To ensure sustainable development (economically, socially and environmentally balanced), it is important to analyze the activities of economic actors in these areas and determine weighted priorities. The prolonged domination of economic determinism has actualized the implementation of corporate social responsibility by economic actors, which, being primarily a voluntary business for enterprises, has a precedent to become mandatory through its legislative normalization. Therefore, the assessments of the social responsibility of agricultural enterprises of the corporate sector given in this article, depending on their economic opportunities and performance, are relevant in the context of moving towards sustainability.

The aim of the article is to substantiate the interaction of agricultural enterprises and explore the levels of corporate social responsibility for individual components of five groups of agricultural enterprises grouped by performance indicators of their economic activities.

The main focus of the study is to test the hypothesis common in Ukraine, large agricultural structures have sufficient potential to implement corporate social responsibility, while small and medium-sized agricultural enterprises allegedly have limited opportunities for socially responsible actions.

The problem addressed in this study is that really economically strong enterprises, having more opportunities, better solve social and environmental problems in the context of corporate responsibility compared to economically weak enterprises. The main focus is on the basic direction of responsibility - relations with employees and landlords - in terms of their material remuneration for labor and the land provided.

Using the method of statistical groupings, five groups were singled out from an array of 9 thousand medium and large agricultural enterprises of Ukraine, which officially report on the statistical form of the main economic indicators of work. According to the characteristics of agricultural enterprises, the amount of revenue and the level of profitability were chosen. The block of social aspects of activity is represented by indicators on the level of reproduction of labor and settlements with landlords, and environmental aspects on the efficiency of land use, rationality of the structure of crops and the structure of production. Using the method of comparing indicators over time, trends have been revealed to strengthen or weaken the socio- 
ecological responsibility of agricultural enterprises of extreme groups (economically weak and economically strong) over a seven-year period.

\section{An analysis of recent research and publications}

In recent times, attention has been focused on the aspects of CSR, related to agribusiness, as noted by Luhmann and Theuvsen (2016). They argue that the followup studies should be aimed particularly at the increasing the value of the CSR industry specific aspects. In the field research of the development of specific agro-business aspects of CSR can be based, for instance, on expert interviews with stakeholders.

Favoring this position, we believe it necessary to underline an importance of formation and analysis of the official statistics base dedicated to the CSR aspects of agricultural enterprises, implemented in this article. Researchers have found out a clear difference between the opinions of agribusiness owners and their behavior in the CSR implementation: owners present themselves as followers of a broad, in other words, modern view of CSR (adherence to the principles of morality, responsibility for a wide range of tasks, including environmental protection, participation in community development, etc.). However, the owners of agricultural enterprises clearly did not agree with the factors, connected to the classical CSR vision. Moreover, as it turned out, such position is close to the miserable life and work conditions of their workers (particularly, immigrant laborers) (Ortega, 2016).

It proves the position of the authors of this article, that in a CSR context, it is important to pay more attention to the enterprise employees. First of all, business should interact with its workers, and with its partners -co-workers, neighbors, authorities, as it's indicated by European Commission (European Commission, 2011). As it's required by the International Labour Organization, enterprises must ensure safe and healthy working conditions for their employees, together with an access to basic health services, education and housing. An intention of agricultural enterprises to save on the employee costs results in the decrease of their subsistence level, inappropriate conditions for life-sustaining activity of a rural community. Narrowed or classical CSR vision involves economic and legal liability for such obligations as generating an income for owners, while there is much less responsibility for the proper distribution of income between the employees.

It's commonly known that among the list of 7 objects, at which a CSR guidance ISO 26000 is focused, few objects are concerned with employees, that is a workforce, and human rights, business practice are next to such objects as environment, consumers, communities and management (Herciu, 2016).

Jamali and Karam (2018) underline that CSR forms are contextualized and formed at the local level with a help of multilevel factors and subjects (Jamali, Karam, 2018). There are significant differences in the way of CSR conceiving, in other words, "CSR Thinking" and the way of its implementation in practice. In this context, statement, that CSR models in agriculture out step the industry and therefore require empirical data to explain the wide variety of standard development and perception within a unique 
context of agriculture, is of importance (Poetz, Haas, Balzarova, 2013). MazurWierzbicka (2015) states that CSR can be used in agriculture as a tool of a constant development. The authors of this article also adhere to this position. The justification of the CSR models in agricultural enterprises will be a subject of further authors' studies, considering a multifunction of such kind of business, complementarity of agrarian and rural development, an importance of a constant agricultural development for the benefit of society.

According to the studies by Levkivska and Levkovych (2017), CSR concept is not fully understood by the heads of Ukrainian agricultural enterprises, and their actions correspond with such wrong perception. A majority of the directors, that were interviewed, consider CSR as an ethical and responsible attitude to their consumers and partners, and as realization of social programs for improving community life (Levkivska, Levkovych, 2017). Gagalyuk and Schaft (2016), noted that Ukrainian agroholdings practice CSR, but only those, which are listed on the International Stock Exchange and have documented activities plan in this sphere. Data provided shows us that the average salary at the agroholdings (as large enterprises) is not much bigger than in other agricultural enterprises, just by $19 \%$ and rent just by $31 \%$ (Gagalyuk, Schaft, 2016). Authors' reflections about the conclusions of researchers, that large agrarian structures, especially agroholdings, had enough potential to spend time and efforts on socially responsible actions, motivated them to write this article. Such enterprises may play an important role in solving and internalization of the existing social problems. In the authors' opinion, small and medium-sized agricultural enterprises have relatively limited abilities for participation in complex CSR programs.

The aim of the research is to prove a differentiated approach to the corporate responsibility formation of the agricultural enterprises depending on their economic status. Greater economic opportunities of the enterprises define their higher corporate responsibility for their employees and communities, realization of adequate social and ecological actions.

\section{Results of research}

Innovations in the CSR context. According to the French Law on Corporate Social Responsibility from 2017, multinational corporations, that do all or a half of their business in France (estimated to cover 150-200 units), establish mechanisms for prevention of human rights abuse and environmental damage in the whole supply chain (Altschuller, 2017). Corporations are required to elaborate a vigilance plan, in which they have to prescribe responsibility and action control in these fields of the main and subsidiary companies, as well as related contractors and suppliers. If a company failed to develop such a plan, it would be penalized (from 10 to 30 million EUR) depending on the degree of the human right violation or environmental damage.

In accordance with the law on new economic rules from 2001 (Chelli, Durocher, Richard, 2014). French companies, which are listed on the stock exchange, should provide social and ecological information in their annual reports. Such information 
should reflect data about an employment (with an analysis of possible obstacles during an employment process), staffing cut, reduction of salary and its dynamics; work conditions and security, integration and social schemes.

According to the EU Directive on the Non-Financial Information Disclosure, beginning from the year 2014, large socially significant enterprises in the EU report on the compliance with the principles of a constant development, and companies with more than 500 employees report starting from the year 2017. The European Business Strategy Manifesto 2020 of the CSR European Movement defines three priorities for enterprises (Europe, 2013): an employment and inclusiveness; an interaction with local communities and regions as with partners in order to implement sustainable methods of production, consumption and life activities; transparency and respect to the human rights as the basis of business behavior.

In Germany, according to the Law on Agriculture (Agrarian laws, 2015) the federal government provides the Bundestag and the Bundesratwith the "Report on the Agricultural Status" every 4 years (since 2011), and such report contains an expert conclusion on how much the salary of the agricultural workforce correspond to the compared professional groups. This is one of the three kinds of reporting, which are legalized as mandatory. It is noted that there is a necessity to balance the existent disadvantages, which are connected to the environmental and economic conditions with a help of economic and agrarian politics, and thus a social status of people, involved in agricultural sphere, should be equaled. So, providing an equal pay for hired and family labour at the level of the average salary in the corresponding professional groups is clearly regulated as one of the most important criteria for the German agricultural development.

The basic principles on which it is advisable to base agricultural enterprises on CSR and comply with generally accepted international approaches are as follows:

- Relationship with employees: equity (including programs for the distribution of profits among employees), support, participation;

- Human rights and international labor standards: compliance, implementation;

- Natural resources: frugality, efficiency, protection

- Society and society: employment, promotion of sustainable development;

- Consumers: respect for rights and interests, product quality and safety;

- Education: investments, advanced training programs;

- Cultural diversity: support and tolerance;

- Fair competition: competition and corruption prevention;

- Corporate governance: leadership transparency; inclusiveness in decision making.

This is not only about the salary maintenance at the minimum level, as in Ukraine. The salary of agricultural workers is $20 \%$ lower than the average level according to the types of economy. Usually, farmers are the poorest people in society and that is unfair. Ukrainian legal norms of CSR in agricultural enterprises should be harmonized with rather strict European norms. 
Basic CSR requirements in Ukraine. Practically, only the observance by enterprises of such social dimensions as minimal salary at the annually determined level and rental payments is regulated at the state level. In the year 2016, monthly average nominal wage of hired workers in agriculture sphere was in 2.7 times higher than the established minimum salary. Although such an excess seems to be significant, it only meets the requirement of the "minimum" of the European Social Charter, according to which the minimum salary should exceed the minimum subsistence level in 2,5 times.

A rent for the farmland, which is one of the agricultural enterprises activity indicators, was about $5 \%$ of a standard estimated money value, at the minimum level, defined by the state.

The economic entities often do not adhere to the standardized environmental requirements of farmland protection and use. Environmentalization of the economic activity spheres, remaining a weak component of a state policy, is stimulated mainly by international obligations of Ukraine and with a help of International Organizations financial support. A share of the commercially unattractive livestock production in the structure of gross output of the corporate agricultural sector has decreased. Almost two thirds of large and medium-sized agricultural enterprises do not keep livestock, while seven years ago their number was $45 \%$.With the livestock raising reduction a sphere for use of the villagers labour was narrowed and also the abilities of soil improvement with a help of fertilizers (the share of fertilized cultivated area is only $2,7 \%$ a year by year) has been strictly limited. The number of employees at the agricultural enterprises has decreased from 4.3 million in 1990and from 2.8 million in 2000 to 469 thousand in the year 2017 (Agriculture of Ukraine, 2018).

Therefore, low social and environmental responsibility of domestic agribusiness is a result of a "management vacuum" (Koval, et. al., 2019). It is important to amplify SCR for employees and for the rural communities as well. One-time measures of agricultural enterprises in support of sport facilities, kindergartens, road construction, etc., as well as making social agreements with the appropriation of funds for the rural infrastructure, that is a common practice today, but such measures are not enough. Systemic actions in a CSR context are needed.

Most enterprises of Ukrainian corporate sector are at the initial stages of the Carroll's pyramid, according to the CSR level (fig.1).Economic determinism and domestic farming commercialization leads to the soil depletion and degradation, and to the strengthening of social problems as well (a release of workers, emptying of local commodity markets).Social and environmental destruction of agriculture is a real threat to the resource-environmental safety and its further development. 


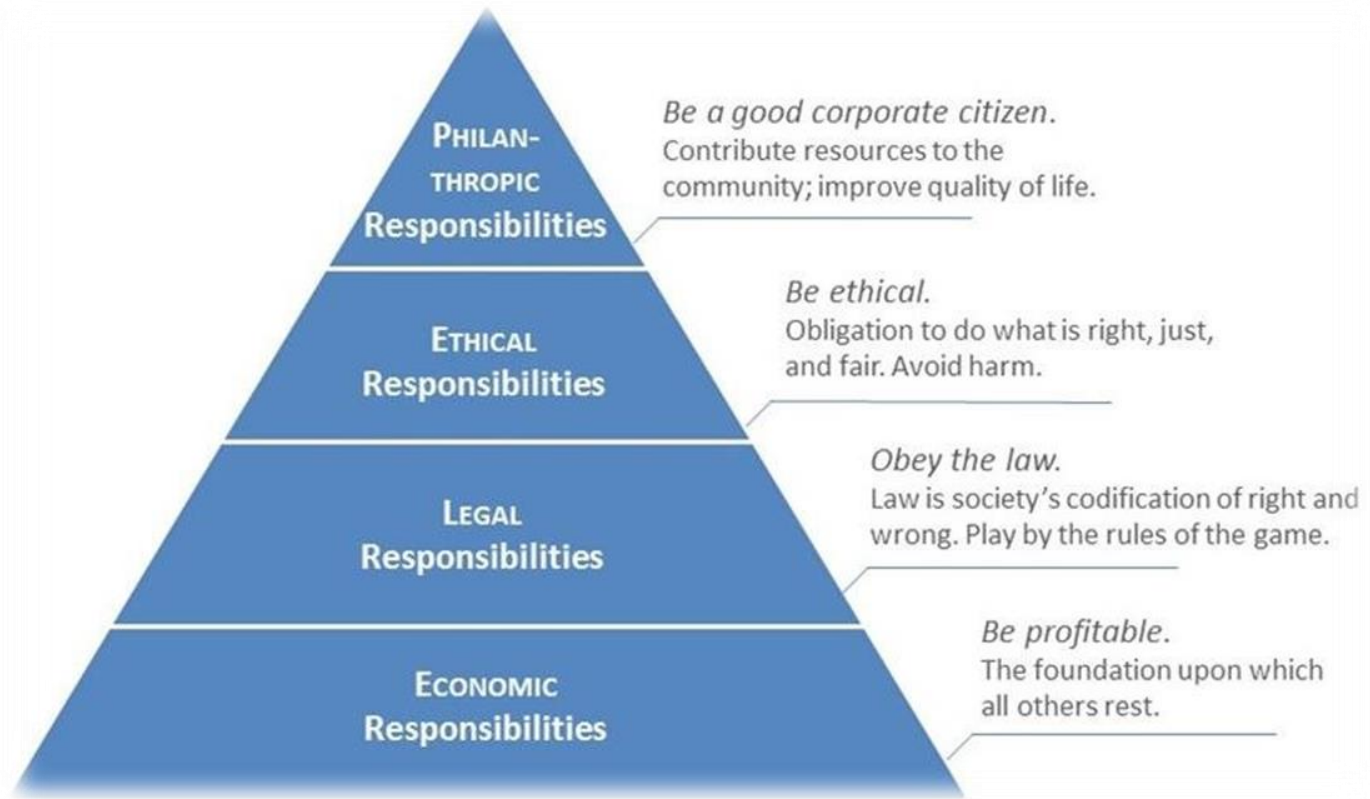

Fig. 1. Pyramid of corporate social responsibility levels

Source: compiled by (Carroll, 1991).

\section{Social and environmental parameters differentiation of agribusiness} activities according to their economic groups. The author studied the hypothesis that economically stronger enterprises allegedly were better at the social and environmental problems solving, with a help of agricultural enterprises informational base of a sevenyear period(about 9 thousand units, which report in accordance with an agricultural form $\left.50^{1}\right)$.Research, dedicated to this topic, started in the year 2008 and preliminary results were published in 2010 (Popova, Pankratova, Betliy, 2010) and in 2015 as well (Agrarian and Rural Development, 2018).

This article, based on the study of the indicators changes during the seven-year period, reflects the tendencies of improvement or worsening of the situation connected with solving social and environmental challenges by economically stronger agricultural enterprises in comparison with weaker ones.

The amount of earnings / revenue from agricultural products sale (reflecting the economic status, the level of production concentrations) and profitability (reflecting the level of economic efficiency, the possibilities of expanded reproduction) were chosen as the classification (grouping) characteristics of agricultural enterprises. It's commonly known, that in the USA statistics the economic classes of farms are distinguish depending on the value of sales (Statistical Abstract, 2018).

\footnotetext{
${ }^{1}$ Calculations were made based on the initial statistic database of agricultural enterprises in the form 50 of the State Statistics Service of Ukraine. It includes medium-sized and large enterprises, which have more than 200 ha of a farmland, or the number of their cattle is more than 50 (big horned livestock, pigs, sheep or goats) or the number of poultry is more than 500. In addition, the average number of employees at such enterprises is more than 20 , or the revenue from agricultural products sale is more than 150 thousand UAH.
} 
Asset of social aspects of the enterprise activity is represented by the indicators, which characterize the levels of workforce reproduction, proper level of rental payments for the farmland use. A set of environmental aspects included the indicators of the farmland use efficiency, of the rationality of crop acreage structure and production structure.

The table number1 shows us the economic growth unevenness (in hundred times) and individual social (in several times, by several percent) and environmental parameters of enterprises activity according to the agricultural products sales profit. It's important to note that the group number I included relatively small agricultural enterprises (with an average farmland area about 300 ha and with 7 employees during the year 2015), and the group number $\mathrm{V}$ included large enterprises (with a farmland area 6,6thousand ha and 155 employees).

A range of income variability in average for the enterprise from groups I to $\mathrm{V}$ was significant, in the year 2009 it was 100 times, and 162 times in the year 2015. A productive resources variability is also high: as for the farmland area and the employees number it's 11 and 22 times correspondently (almost equal in the years studied).

Table 1. Uneven growth of economic, social and ecological activity parameters of the agricultural enterprises according to their different economic opportunities

\begin{tabular}{|l|c|c|}
\hline \multicolumn{1}{|c|}{ Indicators } & \multicolumn{2}{c|}{$\begin{array}{c}\text { Increasing / decreasing from } \\
\text { group number I to the group } \\
\text { number V of the enterprises } \\
\text { according to their sales } \\
\text { revenue }\end{array}$} \\
\cline { 2 - 3 } & 2009 & $2015 *$ \\
\hline Agricultural products sales revenue (thousand UAH) times & 100 & 162 \\
\hline Profitability, percentage points & 39 & 37 \\
\hline Turnover per employee (thousand UAH), times & 8 & 7 \\
\hline Annual payroll per employee (thousand UAH), in times / by \% & 1,6 & $14 \%$ \\
\hline Rental payments per 1 ha of a farmland (UAH), in times / by \% & 2,3 & $30 \%$ \\
\hline $\begin{array}{l}\text { Profitable crops share (wheat, barley, sunflower and rape) of a } \\
\text { cultivated area (\%), percentage points }\end{array}$ & 8 & -5 \\
\hline $\begin{array}{l}\text { Livestock products share of the sales revenue (\%), percentage } \\
\text { points }\end{array}$ & 3 & -18 \\
\hline $\begin{array}{l}\text { Share of the enterprises, that didn't have livestock sales revenue } \\
\text { (\%), percentage points }\end{array}$ & -20 & \\
\hline $\begin{array}{l}\text { Expenses on the mineral fertilizers per hectare of farmland (UAH), } \\
\text { times }\end{array}$ & 6 & 4 \\
\hline
\end{tabular}

* Since the statistical form 50 is shortened from 2017 the number of indicators used in the study is excluded. Therefore, available information basis is being dated by 2015.

Source: The calculations were made based on the primary statistics base of the agricultural reports in the form 50 . 
However, it's clear that significantly larger agricultural enterprises, according to their sales revenue of the agricultural products (and according to the area of their farmland and employee number as well) and thus, top economic rank agricultural enterprises practically haven't differ from the smaller ones in the implementation of socially and environmentally responsible actions. Moreover, if in the year 2009 a salary level at the economically stronger enterprises from group number $\mathrm{V}$ exceeded the relevant indicator of the weaker enterprises from group number I just in 1,6 times, rental payments in 2,3 times as well, then, in the year 2015 the difference between these groups was only a few percent.

It's commonly known that the salary level depends on the enterprises' social activity and its profitability. However, economically effective agriculture enterprises do not hurry to raise the salary, because of the unemployment level, which act as a deterrent, thus workforce excess in the rural area allows the enterprises to save on the salary.

If it's proved in the business literature that a proper ration of the payroll to the sales revenue is within $25 \%$, then the actual ratio, according to the number of the agricultural enterprises studied, is significantly lower. This fact proves a low labour cost in a corporate sector.

Fig. 2 demonstrates a weak ratio of the payroll rate to the sales revenue according to the enterprises groups. If an average sales rate per employee sharply increases from group number I to group number $V$ (in 7 times), the payroll increases only by $14 \%$. The current situation can be characterized as exploitation of workers and agricultural production resources.

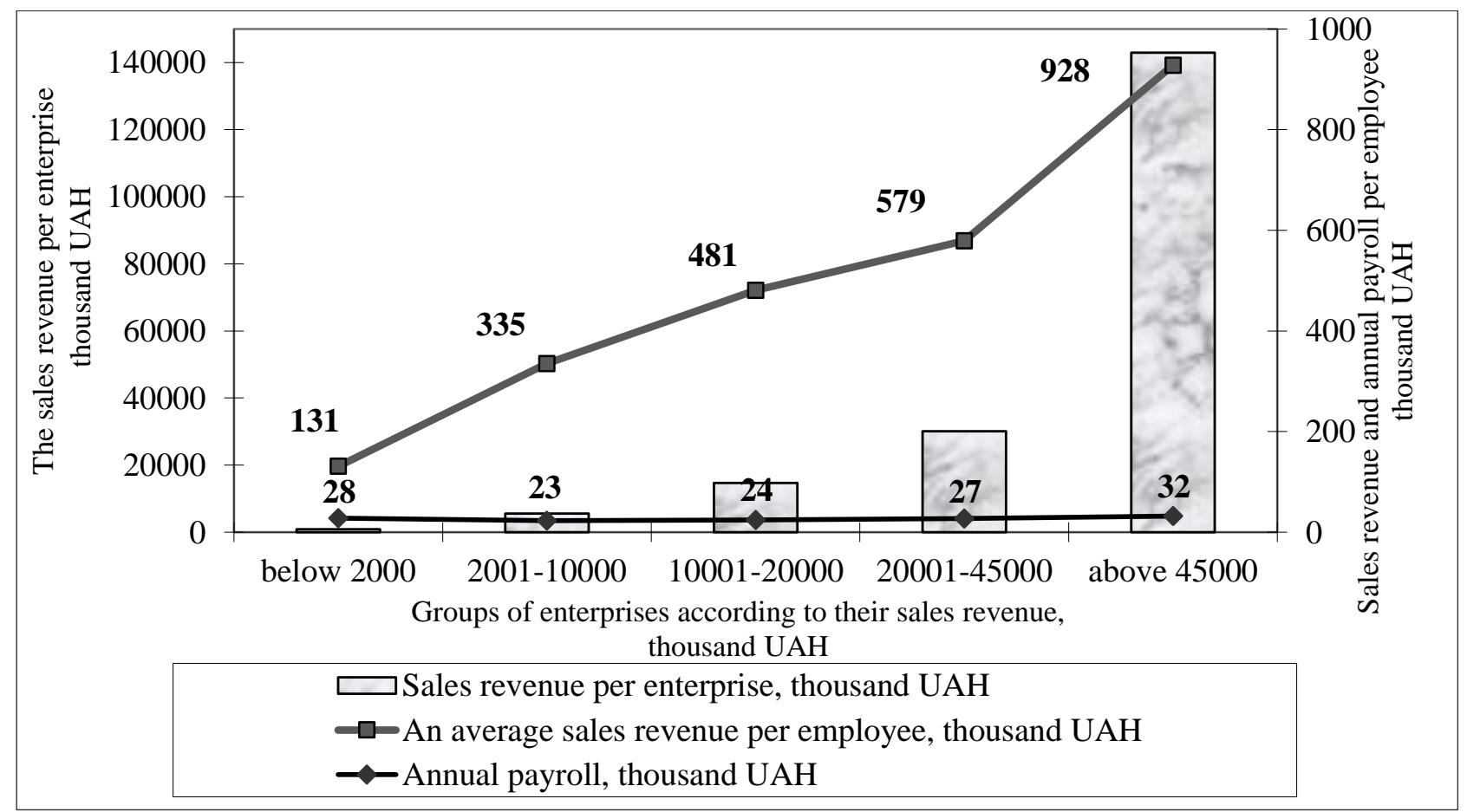

Fig. 2. A demonstration of a weak correlation between a payroll rate and sales revenue according to the groups of enterprises, 2015. 
"Non - market wage rates" is the first of three reasons why employees quit the job, as was noted by personnel directors (HR-Directors) of a range of the large agrarian enterprises (Myronivsky Hliboproduct, Ukrlandfarming, Agroprosperis, Cygnet Agrocompany).

Staff turnover prevails among low-skilled stuff. Such professions as tractor operator and driver are critical for companies, while senior management remains the same (Koval, et. al., 2018). Attention is drawn to new statements and the subject of discussion is whether the old staff is completely dismissed in the case of a company resold or not; and about a significant expansion of the company with the addition of a land bank, but without labor resources. The question is what happened to the employees, that used to work on this land, and a more important one - where to go and where to work after such a transaction with "a land bank without labor force"? At the same time, the directors emphasize that they are socially responsible companies, and point out the social actions they have implemented.

AgroPromholding "Astarta-Kyiv" applied a case for the National CSR Contest 2018 (organized by CSR Development Center), the company prepared a Report of a Constant Development in accordance with the key GRI Standards: Core option (by the way, the information about the employees' salary rate has been not provided).

As for the environmental parameters of activity, all the agricultural enterprises of a different size according to their sales revenue, that were studied, were characterized by the intensive farmland use, and the prevalence of high-profitable crops in the cultivated area structure. The share of a livestock production in the enterprises' sales revenue decreases, that is an evidence of a reduction of such production type, except poultry farming. At the same time, a large number of the enterprises, which did not have any livestock profits, still take a place in the Group I of the relatively smaller agricultural enterprises (66\%), which is due to the unprofitability of the most types of livestock production.

In the majority of large agroholdings, which, as a rule, are preferred by plant water specializations, therefore, there are also few busy workers. The number of livestock per 1 hectare of farmland in them is small, and in all agricultural enterprises accounted for an average of 0.26 conventional heads. Even those agroholdings that position themselves as an enterprise of livestock breeding are not in a hurry to increase their livestock numbers, although they have rapidly increased their land bank. Then it may be necessary to regulate that agricultural enterprises (including agroholding), which maintain crop production, hold 0,5 cows per hectare of agricultural land per hectare of agricultural land. The introduction of this norm will have a social effect through increased employment through labor-intensive livestock production, as well as ecological due to the replenishment of nutrients in the soil due to the introduction of organic fertilizers.

Social responsibility of the agricultural enterprises, which have different profitability level. Enterprises grouping according to their profitability level found out a significant variability of this indicator, starting from minus sign and up to more $100 \%$. However, the increase of the production efficiency of the enterprises from the Group I 
to the Group V of agricultural enterprises had a weak effect in the employees' salary (table 2). An increase of the profitability level of such enterprises was possible due to the higher crop farming commercialization, livestock breeding reduction and production intensification.

Table 2.Uneven change of social and environmental indicators according to the economic efficiency of different agricultural enterprises' activity

\begin{tabular}{|l|c|c|}
\hline \multicolumn{1}{|c|}{ Indicators } & \multicolumn{2}{|c|}{$\begin{array}{c}\text { Increasing / decreasing from } \\
\text { group number I to the group } \\
\text { number V of the agricultural } \\
\text { enterprises according to their } \\
\text { profitability level }\end{array}$} \\
\cline { 2 - 3 } & 2009 & 2015 \\
\hline An average profitability (\%), percentage points & 135 & 169 \\
\hline Agricultural products sales revenue (thousand UAH) times & 3,8 & 2,5 \\
\hline A farmland area per enterprise (ha), times & 1,4 & 1,3 \\
\hline Annual payroll per employee (thousand UAH), \% & 10 & 5 \\
\hline Rental payments per 1 ha of a farmland (UAH), in times & 1,3 & $-0,7$ \\
\hline $\begin{array}{l}\text { Profitable crops share (wheat, barley, sunflower and rape) of a } \\
\text { cultivated area (\%), percentage points }\end{array}$ & -2 & 9 \\
\hline $\begin{array}{l}\text { Livestock products share of the sales revenue (\%), percentage } \\
\text { points }\end{array}$ & $-2,5$ & -8 \\
\hline $\begin{array}{l}\text { Share of the enterprises, that didn't have livestock sales revenue } \\
\text { (\%), percentage points }\end{array}$ & 20 & 26 \\
\hline $\begin{array}{l}\text { Expenses on the mineral fertilizers per hectare of farmland } \\
\text { (UAH), \% }\end{array}$ & 70 & 7 \\
\hline
\end{tabular}

Source: The calculations were made based on the primary statistics base of the agricultural reports in the form 50

The research conducted doesn't allow to prove that the environmental deterioration at the initial stages of economic growth in the reformed Ukrainian corporate agricultural enterprises is permissible, because it will be renewed in a certain period (according to the well-known Kuznets curve). As we can see, despite the economic development, the enterprises do not implement more ecologically responsible actions.

The economic effect of progressive agrarian economics trend in the corporate sector does not spread to a wide range of workers involved and to the rural population and communities, which depend on its development. Practically, earned revenue is concentrated on the accounts of the economically stronger enterprises, enriches a limited range of employers and managers. The negative consequences of such an employers' approach, when they behave like smart egoists, reflect in the limited 
purchasing power of the population because of saving of expenses on the employees' salary and rental payments. Whereas Reich (2012) states that it's important to adhere to the basic premise, which is to give the employees a proportional share of the economic growth benefits, because with the adherence to it the economy remains balanced.

\section{Conclusions}

So, a popular opinion and statement of the many individual researchers that "firstly we will build a strong economy and then we will solve environmental and social problems" does not work in Ukraine. The research conducted shows that, firstly, economically stronger agricultural enterprises, including agro holdings, become stronger (concentrating the resources, increasing the intensity of a land and workforce use) due to the obtaining economies of scale and do not increase properly social and environmental parameters of their activity, saving costs in such a way.

Secondly, the seven-year period studied makes the fact that economically stronger enterprises ignore solving social and environmental problems more obvious.

Thus, the situation when economically stronger enterprises become stronger and weaker enterprises become weaker intensifies the gap between them, when the difference according to their social and ecological activity is practically set off. Agricultural enterprises still consider social and environmental activity as burden and obstacle on the way to the economic progress. They position the one-time social actions as significant in the context of their corporate responsibility. There is no proper CSR system. Control of the adherence to the current standards is weak or absent.

Thirdly, the appropriate "game rules" for business in a context of the implementation of a multifunction character of the agriculture, corporate social responsibility and constant development are insufficiently regulated at the state level. Control of the adherence to the current standards is weak or absent. A public request from citizens, their communities and state for appropriate corporate social responsibility of business should be formed and officially approved.

\section{Prospects for further research}

In the future, it is important to deepen the assessment of various categories of enterprises of Ukraine on economic opportunities, especially agricultural holdings of the type and level of their corporate social responsibility. Although further studies on the method presented in the article are difficult, since the corresponding statistical form is abbreviated and a number of indicators have been deleted. The authors are of the opinion that economically strong enterprises should implement adequate actions on CSR. As it is known, in France it is the large corporations that are obliged to develop a special vigilance plan, in the EU large socially significant enterprises are obliged to report on the observance of the principles of sustainable development and the like. These case studies in Ukraine are important for the development and approval of 


\section{Management Theory and Studies for Rural Business and Infrastructure Development \\ eISSN 2345-0355. 2019. Vol. 41. No. 2: 277-289}

Article DOI: https://doi.org/10.15544/mts.2019.23

standards for proper "rules of the game" for enterprises of the corporate sector in the context of CSR and sustainable development.

\section{References}

Agrarian and Rural Development for Growth and Renewal of the Ukrainian Economy (2018). Scientific Report // National Academy of Sciences of Ukraine, Institute of Economics and Forecasting. - K., 127.

Agrarian laws in Germany (2015). Bundesgesetzblatt Jahrgang 2015 Teil I Nr. 35, ausgegeben am 07.09.2015, Seite 1474. - https://dejure.org/BGB1/2015/BGB1._I_S._1474 Ukraine.

Agriculture of Ukraine 2017 (2018). Statistical collection. K., State Statistics Service of

Altschuller S. (2017). French National Assembly Adopts Corporate Duty of Vigilance Law - https://www.csrandthelaw.com/2017/02/28/french-national-assembly-adopts-corporate-duty-ofvigilance-law

Carroll, A. B. (1991). The pyramid of corporate social responsibility: Toward the moral management of organizational stakeholders // Business horizons, 34(4): 39-49.

Chelli, M., Durocher, S., Richard, J. (2014). France's new economic regulations: insights from institutional legitimacy theory // Accounting, Auditing \& Accountability Journal, 27(2): 283-316.

Europe C. S. R. (2013). Enterprise 2020 Strategy // The European network for corporate social responsibility. Brussels.

European Commission (2011). The European Economic and Social Comittee and the Committee of the Regions. A Renewed EU Strategy for Corporate Social Responsibility. COM (2011) $681 \quad$ Final. lex.europa.eu/LexUriServ/LexUriServ.do?uri=COM:2011:0681:FIN:EN:PDF

Gagalyuk, T., Schaft, F. (2016). Corporate social Reponsibility in agribusiness // Agricultural policy report series. German-Ukrainian Agricultural Policy Dialogue, Kyiv.

Herciu, M. (2016). ISO 26000-An integrative approach of corporate social responsibility // Studies in Business and Economics, 11(1): 73-79.

International Labour Organization. (2008). ILO Declaration on Social Justice for a Fair Globalization No. 1. Geneva: ILO Publications.

Jamali, D., Karam, C. (2018). Corporate social responsibility in developing countries as an emerging field of study // International Journal of Management Reviews, 20(1): 32-61.

Koval, V., Polyezhaev, Y., Bezkhlibna, A. (2018). Communicative competences in enhancing of regional competitiveness in the labour market // Baltic Journal of Economic Studies, 4 (5): 105113. - http://dx.doi.org/10.30525/2256-0742/2018-4-5-105-113

Koval, V.; Petrashevska, A.; Popova, O.; Mikhno, I.; Gaska, K. (2019). Methodology of ecodiagnostics on the example of rural areas // Architecture Civil Engineering Environment, 12(1): 139-144. - http://dx.doi.org/10.21307/ACEE-2019-013

Levkivska, L., Levkovych, I. (2017). Social responsibility in Ukrainian agriculture: the regional issue // Eastern Journal of European Studies, 8(1): 97.

Luhmann, H., Theuvsen, L. (2016). Corporate social responsibility in agribusiness: Literature review and future research directions // Journal of Agricultural and Environmental Ethics, 29(4): 673-696.

Mazur-Wierzbicka, E. (2015). The application of corporate social responsibility in European agriculture // Miscellanea Geographica, 19(1): 19-23.

Ortega, M. I., Sabo, S., Aranda Gallegos, P., Zapien, D., Guernsey, J. E., Zapien, A., ... Rosales, C. (2016). Agribusiness, corporate social responsibility, and health of agricultural Migrant Workers // Frontiers in Public Health, 4: 54. 
Poetz, K., Haas, R., Balzarova, M. (2013). CSR schemes in agribusiness: opening the black box // British Food Journal, 115(1): 47-74.

Popova, O. L., Pankratova, L. L., Betliy, M. G. (2010). Social and environmental parameters of the activity of agricultural enterprises: differentiation by economic classes // Economics and Forecasting, (4): 110-125.

Reich, R. B. (2012). Aftertaste The economy of the future. - M .: Career Press, 7.

Statistical Abstract of the United States (2018). - USA. - Table 862. - 563.

\title{
ŽEMĖS ŪKIO İMONIŲ SOCIALINĖ ATSAKOMYBĖ PAGAL JŲ EKONOMINĖS VEIKLOS POBŪDI
}

\author{
Olga Popova ${ }^{1,}{ }^{*}$ Viktor Koval $^{2}$, Liudmila Antonova ${ }^{3}$, Anna Orel ${ }^{4}$ \\ ${ }^{I}$ Nacionalinè mokslu akademija, Ukraina \\ ${ }^{2}$ Nacionalinis prekybos ir ekonomikos universitetas, Ukraina \\ ${ }^{3}$ DSc., Petro Mohyla juodosios jūros universitetas, Ukraina \\ ${ }^{4}$ Kharkiv nacionalinis technikos unoiversitetas, Ukraina
}

Received 0205 2019; Accepted 30062019

Šiuo tyrimu keliama problema yra ta, ar ekonomiškai stipresnès įmonès, turinčios daugiau galimybių, iš tiesų yra geriau sprendžiančios socialines ir aplinkosaugines problemas socialinès atsakomybès kontekste nei ekonomiškai silpnesnès.

Straipsnio tikslas - pagrịsti žemès ūkio įmonių sąveiką ir ištirti įmonių socialinès atsakomybès lygị atskirose penkiose žemės ūkio įmonių grupèse, suskirstytose pagal jų ekonominès veiklos rodiklius. Naudoti tyrimo metodai - statistinè ịmonių ekonominès veiklos analizè.

Rezultatu skiltyje pateikiami palyginamieji duomenys apie įmonių grupèse labiausiai pasireiškiančią socialinę atsakomybę. Remiantis tyrimo rezultatais, igyvendinant socialiai ir ekologiškai atsakingus veiksmus, žemès ūkio ịmonès, turinčios didesnę ekonominę veiklą, nesiskiria nuo mažesnių.

Raktiniai žodžiai: ekonomika, socialiniai ir ekologiniai iššūkiai, įmonių socialinè atsakomybè, pajamos, pelningumas, ekonomiškai stipresnès imonès.

JEL kodai: D21, L21, M14, Q13.

* Autorius pasiteirauti 